\title{
Blockage of ovulation in the explanted hamster ovary by a collagenase inhibitor
}

\author{
S. Ichikawa, M. Ohta, H. Morioka and S. Murao* \\ Laboratory of Animal Reproduction and * Laboratory of Applied Microbiology, College of \\ Agriculture, University of Osaka Prefecture, Sakai City, Osaka 591, Japan
}

\begin{abstract}
Summary. Hamster ovaries explanted at $21: 00 \mathrm{~h}$ on the day of pro-oestrus were incubated with talopeptin, a potent microbial inhibitor of collagenases, until 10:30 h on the next morning. A talopeptin concentration of $0.16 \mathrm{~mm}$ completely blocked ovulation in vitro. The blocking effect decreased markedly in ovaries excised at $23: 00 \mathrm{~h}$ or later. The results suggest that proteolysis by collagenases is indispensable for the ovulatory process in the hamster.
\end{abstract}

\section{Introduction}

There is considerable evidence implicating collagenolytic enzymes in the ovulatory process of mammalian and avian ovaries (Nakajo, Zakaria \& Imai, 1973; Espey, 1974, 1980; Bjersing \& Cajander, 1975; Okamura, Takenaka, Yajima \& Nishimura, 1980; Fujii, Tojo \& Koga, 1981). Collagenolytic enzymes have been detected in the ovarian follicles of rabbits, sows, women and rats (Espey \& Rondell, 1968; Espey \& Coons, 1976; Morales, Woessner, Howell, Marsh \& LeMaire, 1978; Fukumoto, Yajima, Okamura \& Midorikawa, 1981). However, there is no direct evidence substantiating involvement of collagenases in the ovulatory process. Murao, Katsura, Fukuhara \& Oda (1980) have isolated a potent specific inhibitor of metallo-proteinases, MK-I, from a new strain of Streptomyces, and the inhibitor was recently named talopeptin (Fukuhara, Murao, Nozawa \& Hatano, 1982). In addition we have developed an in-vitro method to ovulate subnormal numbers of ova from hamster ovaries (Morioka \& Ichikawa, 1982). This study was conducted to confirm the hypothesis of collagenase involvement in ovulation by examining the blockage of ovulation in the excised hamster ovary by talopeptin.

\section{Materials and Methods}

Animals. Adult laboratory bred golden hamsters, Mesocricetus auratus, 60-90 days of age and weighing 80-150 g, were used. Animals were housed at $24 \pm 2^{\circ} \mathrm{C}$ under a lighting schedule of $14 \mathrm{~h}$ light $(05: 00-19: 00 \mathrm{~h})$. Vaginal smears were examined every morning. Only females which showed more than 3 consecutive 4-day cycles were used. In these conditions the hamsters ovulated $12 \cdot 3 \pm$ 0.4 ova (mean \pm s.e.m., $n=15$ ), and ovulation occurred between $00: 00$ and $02: 00 \mathrm{~h}$ on the day of oestrus which is characterized by a conspicuous vaginal discharge (Morioka \& Ichikawa, 1982).

Incubation of the ovary. Animals were killed by decapitation on the day of pro-oestrus at specified times $\pm 15 \mathrm{~min}$ between $21: 00$ and $24: 00 \mathrm{~h}$. All ovaries explanted at $21: 00 \mathrm{~h}$ or later on the day of pro-oestrus ovulated a mean number of $4 \cdot 6-4 \cdot 7$ ova but those excised at $19: 00 \mathrm{~h}$ or earlier rarely ovulated (Morioka \& Ichikawa, 1982). The ovaries were placed in Petri dishes filled with Hanks' solution (Hanks \& Wallace, 1949). Fat, ovarian bursa and oviduct were removed 
aseptically. The ovaries were cultured by the procedure described by Morioka \& Ichikawa (1982). Briefly the ovaries were rinsed in a fresh culture medium and placed separately on a stainless-steel wire table ( $2.2 \mathrm{~mm}$ in height) in each culture vessel which contained $2.5 \mathrm{ml}$ culture medium. A Petri dish of $3.5 \mathrm{~cm}$ i.d. was used as the culture vessel. A volume of $2.5 \mathrm{ml}$ medium had a depth of $2.6 \mathrm{~mm}$ in the vessel, and the surface of the table was $0.4 \mathrm{~mm}$ lower than the fluid level. Since the mean \pm s.e.m. diameter of the ovaries was $2.3 \pm 0.0 \mathrm{~mm}(n=10)$, they were cultivated at the surface of the medium. It took about $4 \mathrm{~min}$ for each ovary to be excised and immersed in the culture medium. The loaded culture vessels were placed in a plastic culture chamber and immediately gassed with $95 \%$ $\mathrm{O}_{2}: 5 \% \mathrm{CO}_{2}$ for $15 \mathrm{~min}$ at the rate of 1.5 litres per min. The humidity of the chamber room was maintained by placing wet cotton on the bottom of the chamber. The culture chamber was housed in an incubator at $37^{\circ} \mathrm{C}$. The ovaries were incubated until 10:30 h the following day. Calf serum was then added to the culture medium to prevent adhesion of the ova to the vessel wall. The final concentration of calf serum was $15 \%$. The vessel was gently shaken by hand to free the ova from the vessel wall. The ova shed in the medium were counted under a dissecting microscope.

Chemicals. The basic medium was Medium 199 (Nissui, Co., Tokyo) supplemented with $3.0 \mathrm{mg}$ glucose, $0.1 \mathrm{mg} \mathrm{L}$-glutamine, $0.05 \mathrm{mg}$ ascorbic acid, $0.035 \mathrm{mg}$ insulin, $1.9 \mathrm{mg}$ sodium bicarbonate, 100 units of penicillin and $0.12 \mathrm{mg}$ streptomycin per ml; the osmolarity was 270 mosmol. Talopeptin (6-deoxy- $\alpha$-L-talopyranosyloxyphospho-L-leucyl-L-tryptophan, MK-I) was isolated from culture filtrates of Streptomyces mozunensis MK-23. The inhibitor was dissolved in saline $(9 \mathrm{~g}$ $\mathrm{NaCl} / \mathrm{l}$ ) at a concentration of $0.5,2,4$ and $8 \mathrm{~mm}$. The culture medium was prepared by adding $0.4 \mathrm{ml}$ of the inhibitor solution to $10 \mathrm{ml}$ of the basic medium. Control ovaries were incubated in the same basic medium to which $0.4 \mathrm{ml}$ saline was added in place of the inhibitor solution.

\section{Results}

Dose of talopeptin for ovulatory blockage in the explanted hamster ovary

As shown in Table 1, talopeptin at a concentration of $0.02 \mathrm{~mm}$ significantly decreased the average number of ova ovulated per ovary. At concentrations of 0.16 and $0.32 \mathrm{~mm}$ only one ovum was ovulated from the 20 ovaries examined.

Table 1. Effect of talopeptin concentration on ovulation of hamster ovaries explanted at $21: 00 \mathrm{~h}$ on the day of pro-oestrus

\begin{tabular}{lcccc}
\hline $\begin{array}{c}\text { Talopeptin } \\
\text { conc. } \\
\text { (mM) }\end{array}$ & $\begin{array}{c}\text { No. of } \\
\text { ovaries } \\
\text { examined }\end{array}$ & $\begin{array}{c}\text { No. of } \\
\text { ovaries } \\
\text { ovulating }\end{array}$ & $\begin{array}{c}\text { No. of } \\
\text { ova } \\
\text { ovulated }\end{array}$ & $\begin{array}{c}\text { Mean } \pm \text { s.e.m. (range) } \\
\text { no. of ova/ovary }\end{array}$ \\
\hline 0 & 10 & 10 & 45 & $4 \cdot 5 \pm 0 \cdot 3^{\mathrm{a}}(3-6)$ \\
0.02 & 10 & 10 & 30 & $3.0 \pm 0 \cdot 3^{\mathrm{b}}(2-5)$ \\
0.08 & 10 & 5 & 8 & $0.8 \pm 0 \cdot 3^{\mathrm{c}}(0-2)$ \\
0.16 & 12 & 0 & 0 & 0 \\
0.32 & 8 & 1 & 1 & $0 \cdot 1 \pm 0 \cdot 1^{\mathrm{c}}(0-1)$ \\
\hline
\end{tabular}

Means with different superscripts differ significantly, $P<0.01$.

Time required by talopeptin to block ovulation in the explanted ovary

As shown in Table 2, $0.16 \mathrm{~mm}$-talopeptin completely blocked ovulation from 14 of 16 ovaries which were explanted at $21: 00$ and $22: 00 \mathrm{~h}$ on the day of pro-oestrus. The inhibitory effect of talopeptin markedly decreased when the ovaries were explanted at 23:00 and 24:00 h. 
Table 2. Effect of $0 \cdot 16 \mathrm{~mm}$-talopeptin on ovulation of hamster ovaries explanted between $21: 00$ and $24: 00 \mathrm{~h}$ on the day of pro-oestrus

\begin{tabular}{ccccc}
\hline $\begin{array}{c}\text { Time of } \\
\text { explantation } \\
\text { (h) }\end{array}$ & $\begin{array}{c}\text { No. of } \\
\text { ovaries } \\
\text { examined }\end{array}$ & $\begin{array}{c}\text { No. of } \\
\text { ovaries } \\
\text { ovulating }\end{array}$ & $\begin{array}{c}\text { Total no. } \\
\text { of ova } \\
\text { ovulated }\end{array}$ & $\begin{array}{c}\text { Mean } \pm \text { s.e.m. (range) } \\
\text { no. of ova/ovary }\end{array}$ \\
\hline $21: 00$ & 8 & 0 & 0 & 0 \\
$22: 00$ & 8 & 2 & 3 & $0 \cdot 4 \pm 0 \cdot 3^{\mathrm{a}}(0-2)$ \\
$23: 00$ & 8 & 8 & 22 & $2 \cdot 8 \pm 0 \cdot 5^{\mathrm{b}}(1-5)$ \\
$24: 00$ & 8 & 8 & 25 & $3 \cdot 1 \pm 0.5^{\mathrm{b}}(1-5)$ \\
\hline
\end{tabular}

Means with different superscripts differ significantly, $P<0.01$.

\section{Discussion}

Since talopeptin strongly inhibits metallo-proteinases and slightly inhibits carboxypeptidase, but does not inhibit trypsin, chymotrypsin, papain or pepsin (Murao et al., 1980), the present results indicate that collagenolysis is one of the indispensable factors in the ovulatory process in the hamster ovary. Ovulation blockage by talopeptin in the explanted ovary decreased markedly when the ovary was excised at $23: 00 \mathrm{~h}$ on the day of pro-oestrus, but the integrity of the apex of the Graafian follicle at this time was still maintained. Since ovulation begins in vivo at $00: 00 \mathrm{~h}$ or later on the day of oestrus, collagenolytic degradation of the follicle wall may have reached by $23: 00 \mathrm{~h} \mathrm{a}$ critical stage that inevitably allowed the follicles without collagenase to rupture, or other physiological event, such as proteolytic degradation of a tissue matrix other than collagenous framework may follow the collagenolysis before rupture. These must be evaluated in future studies.

This work was supported in part by Scientific Research Grant No. 57560285 from the Japan Ministry of Education.

\section{References}

Bjersing, L. \& Cajander, S. (1975) Ovulation and the role of the ovarian surface epithelium. Experimentia 31, $605-608$.

Espey, L.L. (1974) Ovarian proteolytic enzymes and ovulation. Biol. Reprod. 10, 216-235.

Espey, L.L. (1980) Ovulation as an inflammatory reaction-a hypothesis. Biol. Reprod. 22, 73-106.

Epsey, L.L. \& Coons, P.J. (1976) Factors which influence ovulatory degradation of rabbit ovarian follicles. Biol. Reprod. 14, 233-245.

Espey, L.L. \& Rondell, P. (1968) Collagenolytic activity in the rabbit and sow Graafian follicle during ovulation. Am. J. Physiol. 214, 326-329.

Fujii, M., Tojo, H. \& Koga, K. (1981) Detection and properties of collagenase in ovarian follicle wall of domestic fowl (Gallus domesticus). Int. J. Biochem. 13, 1044-1046.

Fukuhara, K., Murao, S., Nozawa, T. \& Hatano, M. (1982) Structural elucidation of talopeptin (MK-I), a novel metallo proteinase inhibitor produced by Streptomyces mozunensis MK-23. Tetrahedron Lett. 23, 2319-2322.

Fukumoto, M., Yajima, Y., Okamura, H. \& Midorikawa, O. (1981) Collagenolytic enzyme activity in human ovary: an ovulatory enzyme system. Fert. Steril. 36, 746-750.
Hanks, J.H. \& Wallace, R.E. (1949) Relation of oxygen and temperature in the preservation of tissues by refrigeration. Proc. Soc. Exp. Biol. Med. 71, 196-200.

Morales, T.I., Woessner, J.F., Howell, D.S., Marsh, J.M. \& LeMaire, W.J. (1978) A microassay for the direct demonstration of collagenolytic activity in Graafian follicles of the rat. Biochem. Biophys. Acta 524, 428434.

Morioka, H. \& Ichikawa, S. (1982) Ovulation in explanted hamster ovary. Japan. J. Anim. Reprod. 28, 201-205.

Murao, S., Katsura, M., Fukuhara, K. \& Oda, K. (1980) New metallo proteinase inhibitor (MK-I) produced by Streptomyces mozunensis MK-23. Agric. Biol. Chem. 44, 701-703.

Nakajo, A., Zakaria, H. \& Imai, K. (1973) Effect of the local administration of proteolytic enzymes on the rupture of the ovarian follicle in the domestic fowl, Gallus domesticus. J. Reprod. Fert. 34, 235-240.

Okamura, H., Takenaka, A., Yajima, Y. \& Nishimura, T. (1980) Ovulatory changes in the wall at the apex of the human Graafian follicle. J. Reprod. Fert. 58, 153155. 